Denis Aleksiejev (Денис Алексеев)

Uniwersytet Technologii Przemysłowych i Wzornictwa w Sankt Petersburgu, Wyższa Szkoła Technologii i Energetyki

iD ORCID: 0000-0001-9701-8482

Aleksey Kozhemyakin (Алексей Кожемякин)

Uniwersytet Technologii Przemysłowych i Wzornictwa w Sankt Petersburgu
OBLICZA WOJNY

TOM 4 - MIASTO I WOJNA

ŁÓDŹ2021 • ISBN 978-83-8220-617-3•s.345-368

https://doi.org/10.18778/8220-617-3.17

iD ORCID: 0000-0002-1644-5093

Yuliya Minutina-Lobanova (Юлия Минутина-Лобанова)

Uniwersytet Technologii Przemysłowych i Wzornictwa w Sankt Petersburgu

iD ORCID: 0000-0003-2633-8387

\title{
СПЕЦИФИКА ЮГО-ЗАПАДНЫХ ОКРАИН ЛЕНИНГРАДА ВО ВРЕМЯ БЛОКАДЫ (1941-1944)
}

Streszczenie. W czasie oblężenia Leningradu (1941-1944) najbardziej niezwykłe były losy jego południowo-zachodnich przedmieść, na które składają się obecnie okręgi: Kirowski i Krasnoselski. Dzielnica Krasnoselska była jedyną częścią nowoczesnego Petersburga, która została zajęta przez Niemców. Jej mieszkańcy cierpieli z powodu przymusowych wysiedleń i polityki terroru okupantów. Z kolei Kirowski stanowił pierwszą linię obrony radzieckiej. Nie bacząc na to, w ulokowanych tam fabrykach starano się dalej pracować. Niemniej jednak obie dzielnice łączyło wiele wspólnego: głód, ostrzał artyleryjski (z różnych stron), całkowite zniszczenie infrastruktury, wyludnienie. Po wojnie obie dzielnice zamieniły się w wielki plac budowy, na którym realizowane były pierwsze projekty wznoszone $z$ wielkiej płyty w stylu radzieckim. Obecnie dzielnice posiadają wiele miejsc pamięci związanych z II wojną światową - stare bunkry, cmentarze żołnierskie, pomniki, tablice pamiątkowe. Większość tutejszych ulic nosi nazwy przypominające wydarzenia związane z oblężeniem Leningradu i II wojną światową.

Słowa kluczowe: Il wojna światowa, front radziecko-niemiecki, oblężenie Leningradu, południowo-zachodnie przedmieścia Leningradu, miasto, okupacja niemiecka

Юго-западная часть современного Санкт-Петербурга - Кировский и Красносельский районы. Их современные границы сформированы в 1973 г., однако у этих мест Аавняя история, уходящая в среАние века. 
КогАа-то эти места осваивали ижора и славяне, позднее тут появились финские крестьяне, а в XIX в. - немецкие колонисты. 3Аесь выращивали хлеб и занимались рыболовством. При Петре через эти места пролегла Петергофская дорога, тогда же здесь заработали первые промышиенные преАприятия. Со временем именно индустриальная функция стала главной. Высока была политическая активность жителей: здесь прошла первая в России революционная маевка, отсюда начались обе русские революции. После 1917 г. началось вхождение юго-западных земемь в черту города. В 20-е годы здесь стартовал эксперимент по превращению рабочих окраин в полноценные городские кварталы. Строились жилые массивы, школы, первые в Аенинграде объекты в своем роде, как, например, Аом культуры имени Горького. Начальный участок Петергофского шоссе был превращен в одну из главных городских магистралей - проспект Стачек. Огромна была экономическая роль юго-западных территорий - здесь Аействовац еАинственный в то время советский порт на Балтике, создавался стратегически важный отечественный искусственный каучук, началось производство первых в СССР пишущих машин ${ }^{1}$.

22 июня 1941 г. началась Великая Отечественная война. АенинграА в это время был пятым городом в мире по числу жителей: в нем проживало около 3,5 млн человек. Жители юго-запада раздемили общую судьбу с Аенинградом и $е$ енинграАской областью: их коснулись мобилизация в Красную армию, эвакуация вглубь СССР, строительство укреплений и противовоздушных убежищ. С Аругой стороны, судьба именно этих районов обладала своей спецификой, отличавшей их от судеб житемей остальных районов города. КогАа в сентябре 1941 г. волна вражеского наступления докатилась до юго-западных рубежей Аенинграда, Аиния фронта прошла таким образом, что Красносельский район в современных границах оказался в зоне оккупации, а Кировский район стал переАним краем обороны Красной армии. Примерно по современной границе Авух районов пролегла Аиния фронта, остававшаяся стабильной до января 1944 г. Прифронтовые части обоих районов разделими участь фронтовых и прифронтовых местностей, которые почти полностью утратили

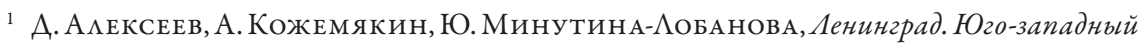
рубеж, Санкт-Петербу'рг 2020, s. 5-11.
} 
застройку и инфраструктуру. В течение трех мет зАесь шла позиционная борьба, в ходе которой постоянно сооружались и разрушацись оборонитемьные сооружения.

Важные изменения коснулись демографии юго-запада. В июне-августе часть жителей районов ушли в армию. За время войны свыше 400 тыс. менинградцев отправимось защищать Родину. Сколько из них не верну$\Lambda$ ось, неизвестно до сих пор ${ }^{2}$.

Организованная эвакуация в восточные районы СССР коснулась только части жителей Кировского района - тех, кто работал на оборонных заводах, подлежавших эвакуации согласно преАвоенным планам, а также членов их семей. Так, значитецьная часть оборудования Кировского завода, вместе с рабочими и конструкторами, были вывезены в Челябинск, чтобы всю войну снабжать танками Красную армию. Эвакуация из Аенинграда велась в основном железнодорожным транспортом и проходима при помощи аАминистрации заводов, эвакопунктов и городской железнодорожной станции. Массовая эвакуация гражданского населения не преАполагалась: считалось, что со стороны Германии АенинграА прикроет Прибалтика. За время плановой эвакуации с 29 июня до 8 сентября 1941 г. вкцючительно из Аенинграда эвакуировацось 706283 человека, в том числе заводы эвакуироваци 164320 человек, райсоветы - 401748 человек, эвакопункты - 117580 чемовек и городская железнодорожная станция - 22635 человек. Всего по Аанным городской эвакуационной комиссии до начала блокады из города выехали 488703 менинградца и 147500 жителей Прибалтики и $\Lambda$ енинградской области ${ }^{3}$.

Статистика по эвакуированным в привязке к отдемьным районам не велась. Оценочно в Аетние месяцы 1941 г. территорию нынешних Кировского и Красносельского районов покинуло около $5 \%$ жителей - мобимизованных и эвакуированных.

2 О.Ф. Сувениров, Помощь Аенинграда фронтулюдьми в первую блокадную зиму. Вторая мировая война, Кн. 2: Военное искусство, Москва 1966, s. 157-166.

3 Ю.З. КАнтор, Эвакуачия из Аенинграда и Аенинградской области, [w:] Побратимьь. Регионам, принявиим эвакуированныхленинградиев, посвяшается, реА. Ю.З. Кантор, СанктПетербу́рг 2019, s. 9-54. 


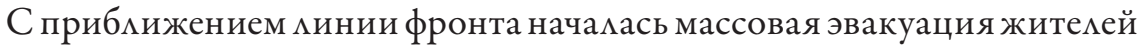
Красносельского и Кировского районов в северные районы $е$ енинрада. В начале сентября 1941 г. колхозы и совхозы Красносельского района организованно вывезци часть имущества и перегнали скот в северные районы Аенинграда (им. 1). Территория севернее окружной железнодорожной магистраци (Путимовской ветки) быма объявлена прифронтовой зоной и закрыта Аля свободного перемещения частных $\Lambda$ иц. В нее вош а

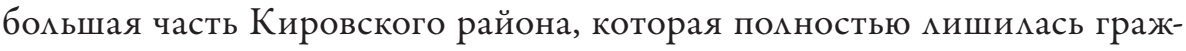
Аанского населения (им. 2).

Эвакуированные не имеми возможности взять с собой много продовольствия и вещей, в результате они оказацись в худшем положении, чем жители Аругих районов города, которые пользовацись оставшимися в квартирах запасами продовольствия и могли продавать ими обменивать на еАу свои вещи. Голодной зимой 1941/1942 г. многие из эвакуированных пытались пробираться домой сквозь заставы и патрули в надежде найти в оставценных жимищах еду и вещи Аля обмена. Оценочно смертность среАи них в первую блокаАную зиму была выше, чем среди менинградцев, оставшихся в своих квартирах. Например, когда 3 декабря 1941 г. на эвакопункт Борисова Грива прибым эшелон с 2 тыс.

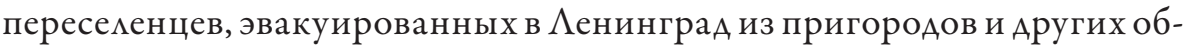

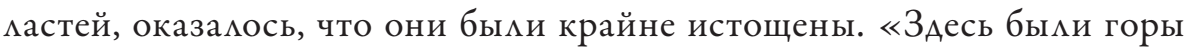
трупов. Мы размещали до 200 чел. Из них 50 \% умирали» ${ }^{4}$.

В числе экстренных мер, которые начами приниматься в первые Ани и Ааже часы войны, было переоборудование школ и Аетских садов Аля военных нужА. Во многих учебных зАаниях разместици военные госпитали, призывные и эвакуационные пункты и т. п. Некоторые зАания переоборудовали частично - например, в здании школы № 6 Кировского района (сейчас - школа № 384) нижний этаж был приспособлен Аля размещения зенитчиков, на третьем этаже разместици военкомат, на четвер-

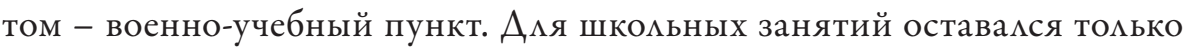
второй этаж зАания (им. 3).

${ }^{4}$ В.А. Пянкевич, А.Н. Чистиков, Пешком по озеру: эвакуащия населения из Аенинграда в конще ноября-начале декабря 1941 г., „Новейшая история России” 2019, т. 9, №1, s. 62. 


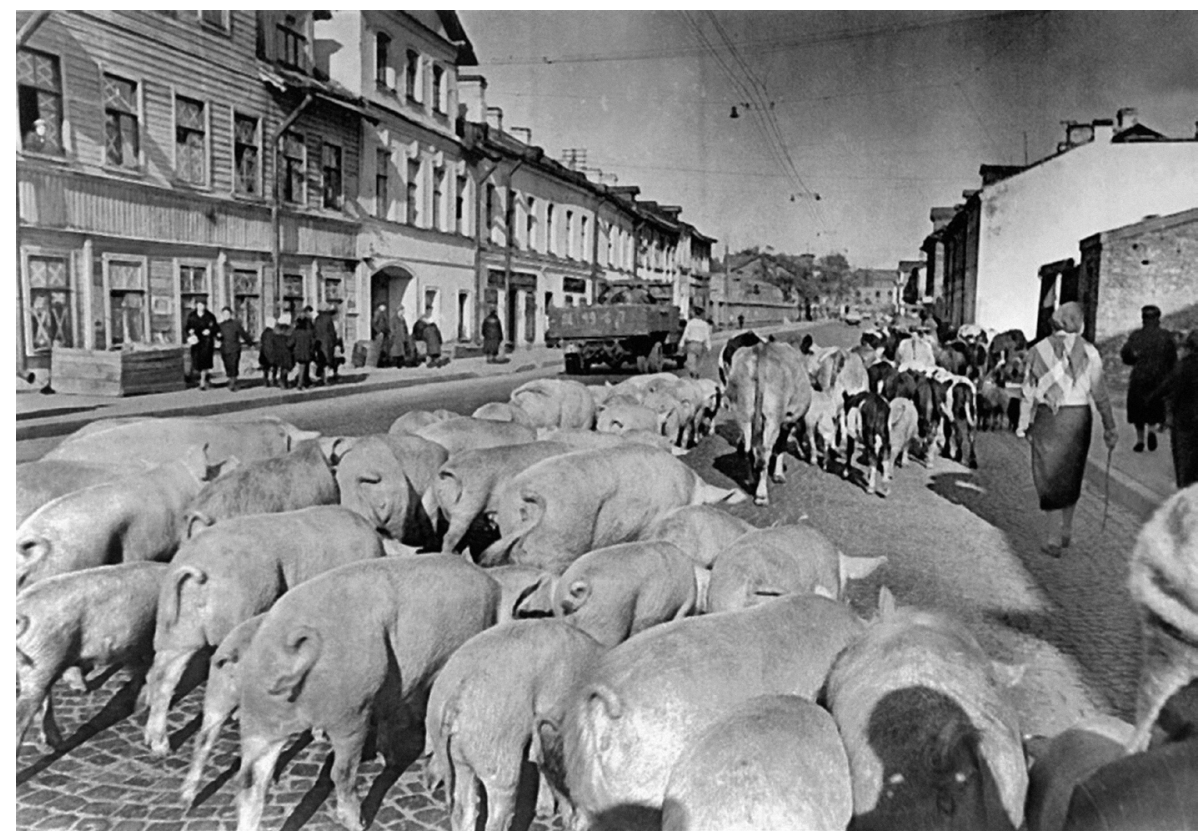

Ил. 1. Угон скота из Ленинградской области. Кировский район, Новосивковская улица (сейчас улица Ивана Черных). 17 сентября 1941 г. (Фот. В.Г. Федосеев, ЦГАКФФД СПб)

30 июня 1941 г. начаца формироваться Аенинградская армия народного ополчения. В первые недели войны многие менинградцы, в том числе жители Кировского района, Аобровольно записацись в народное ополчение. Из них было сформировано несколько Аивизий, которые стаци тем резервом, который прикрыл город в самые тяжемые моменты вражеского наступления. Всего к концу сентября 1941 г.

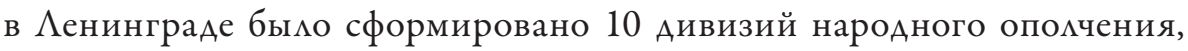
14 пулеметно-артимцерийских батацьонов, 7 истребитемьно-партизанских полков, несколько истребительных батальонов и Аругих формирований, в общей сложности насчитывавших около 160000 человек 5 .

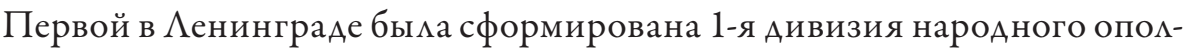
чения, состоявшая из добровольцев Кировского района. Ее формирование проходило в зАании Аома культуры имени Горького. 1-й полк формировац Кировский завоА, 2-й полк - Судостроительный завоА

\footnotetext{
5 Блокада рассекреченная, сост. В.И. Аемидов, Санкт-Петербург 1995, s. 41-49.
} 
им. ЖАанова, 3-й полк - Аругие преАприятия района. 10 июля 1941 г. Аивизия выступима на фронт. В августе 1941 г. Аивизия приняла участие в тяжелых боях на Аужском рубеже и попа а в окружение. С большими потерями ее отдемьные части пробимись к своим и продомжими оборонять Менинград.

Помимо народного опоцчения, представцявшего собой части ААя борьбы непосредственно на фронте, в Аенинграде летом 1941 г. из добровольцев формировались и Аругие виды войск: истребительные батамьоны Аля борьбы с Аиверсантами, а также партизанские отряды, подготовленные Аля переброски в тым противника. Рабочие, оставленные на предприятиях, проходими военное обучение и зачислямись в рабочие отряды и батацьоны, которые стали бы последним резервом в случае прорыва врага внутрь города. Рабочие батацьоны рассматривацись как одно из важных звеньев обороны города. Они комплектовацись по производственному принципу, в их состав вкцючацись те, кто прошел краткий курс военного обучения без отрыва от производства. Большинство рабочих батальонов было сформировано в очень короткий срок - с 19 по

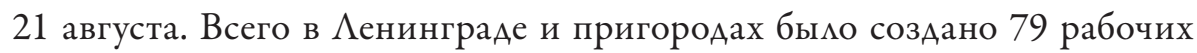
батацьонов, в которых числилось 41255 человек. 19 августа 1941 г. на Кировском заводе начато формирование рабочего батацьона. Его бойцы патрулировали улицы района и явля ись ближайшим резервом Аля частей Аействующей армии 6 (им. 4).

Немецкие войска рвацись к Аенинграду с нескольких направлений, в том числе со стороны Нарвского шоссе. ЗАесь важным препятствием на их пути было Красное Село, явмявшееся опорным пунктом Красногвардейского (Красногвардейском тогда называцась Гатчина) укрепленного района, состоявшим из 4 батальонных районов обороны. В нем бымо построено 69 артилмерийских и 22 пулеметных Азота, 4 артилмерийских Аота, 28,5 км окопов и ходов сообщения, отрыто 12,5 км рвов и эскарпов.

${ }^{6}$ И.Ю. СавраСов, Кировскийзавод вгоды Великой Отечественнойвойнь, [w:] Аенинград. Война. Блокада. Город-фронт, сост. П.В. Игнатьев, Э.А. Коршунов, А.И. Рупасов, СанктПетербург 2019, s. 461-464. 


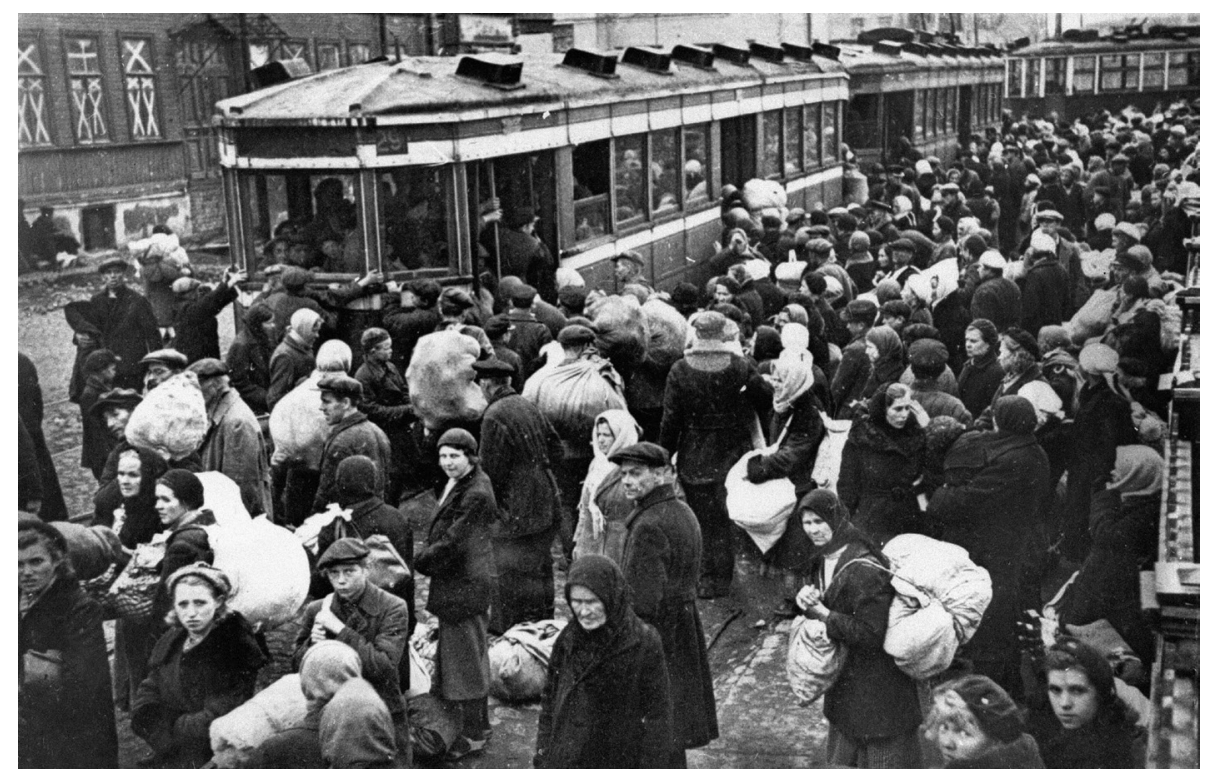

Ил. 2. Посадка на трамвай жителей, эвакуируемых из Кировского района. 18 сентября 1941 г. (Фот. неизвестен, ЦГАКФФД СПб)

9 сентября противник симами 1-й пехотной Аивизии начац наступление на село Русско-Высоцкое, где Нарвское шоссе перехватывалось полосой обороны Красногвардейского укрепленного района. ЗАесь его встретили части 3-й гварАейской Аивизии народного ополчения при поААержке трех отдельных пулеметно-артициерийских батацьонов, также состоявших из менинграАских ополченцев. Чтобы прорвать советские укрепления, немцы собрали перед Русско-Высоцким мощный артилмерийский кулак, вк ючавший все возможные орудия вплоть до зенитных. Несмотря на это, преодолеть советскую оборону в течение 9 сентября враг не сумем.

Юго-западнее, у деревни Скворицы, начама наступление немецкая 36-я моторизованная дивизия. Уже в первый день наступления противник при поААержке пикирующих бомбарАировщиков преодолеА советские укрепления, хотя штурмовавшая Аеревню немецкая Аивизия понесла в тот день самые большие потери с первого Аня войны - 51 убитый и 248 раненых. Прорвавшись к деревне Аропаккузи, немцы выш ии к Аудергофу. Во втором эшелоне следоваци 1-я и 6-я танковые Аивизии, 


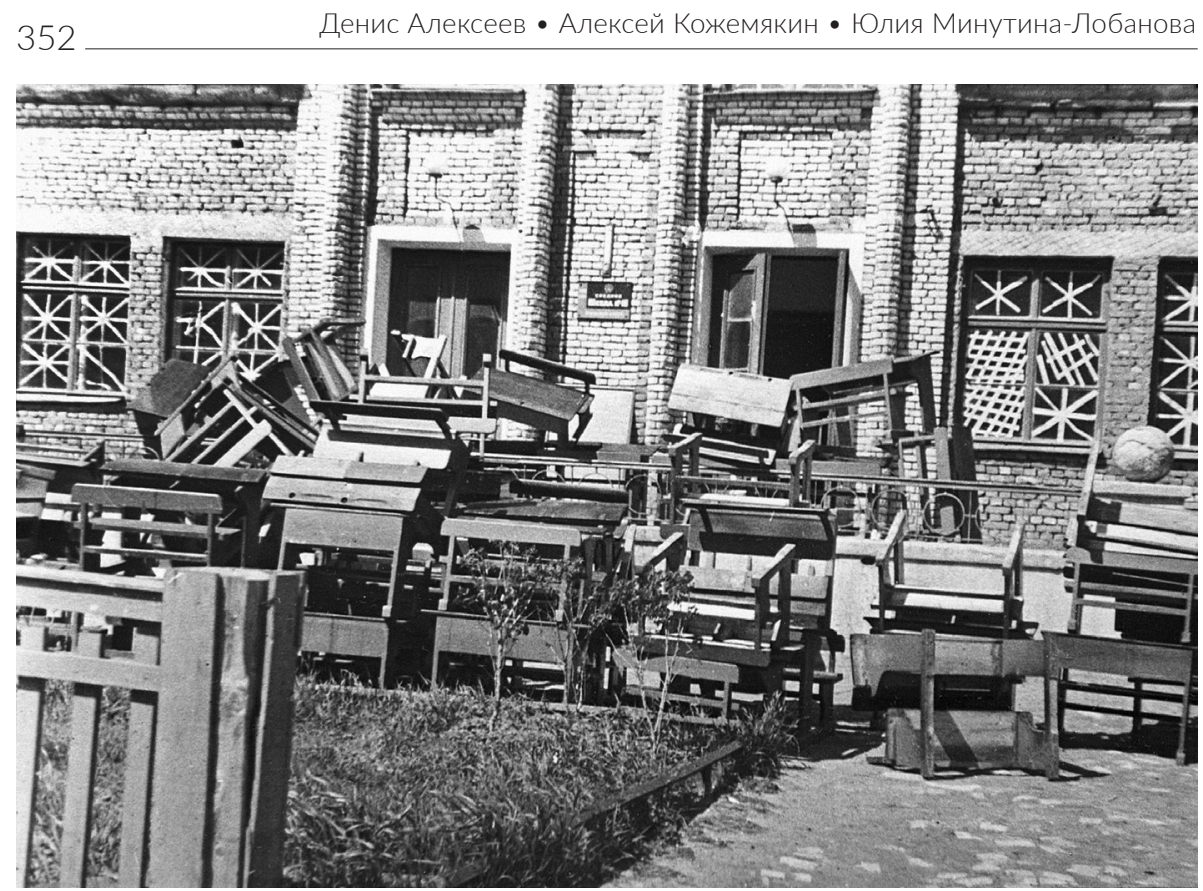

Ил. 3. Подготовка одной из школ Кировского района под лазарет. 27 июня 1941 г.

(Фот. И.М. Анцелович, ЦГАКФФД СПб)

готовые развить успех. Резервов, чтобы отразить этот удар, у командования советской 42-й армии не было. 10 сентября 1941 г. противник вышем на бцижние подступы к Красному Селу. К 11 сентября немцам УАалось преодолеть $\Lambda$ инию обороны Красносемьского сектора и начать продвижение по Нарвскому шоссе. 36-я моторизованная дивизия заняма Аудергоф и территорию магеря под Вороньей горойㄱ.

14 сентября 1941 г. из-за поврежАения подстанции на Петергофском шоссе остановицись около 20 трамвайных составов, использовавшихся Аля эвакуации раненых. Во время Вемикой Отечественной войны трамвайная $\Lambda$ иния до Стрельны использовалась как дополнительная коммуникация с войсками 8-й армии, оказавшимися на Копорском плато. В середине сентября около Авадцати трамвайных составов со всего го-

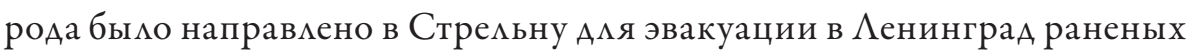

7 В.А. Мосунов, Борьба за Пулковский рубеж в сентябре 1941 года, [w:] Война и оружие. Новые исследования и материаль. Труды Третьей Международной научно-практической конферениии 16-18 мая 2012 года, реА. С.В. Ефимов, Санкт-Петербург 2012, s. 384-399. 


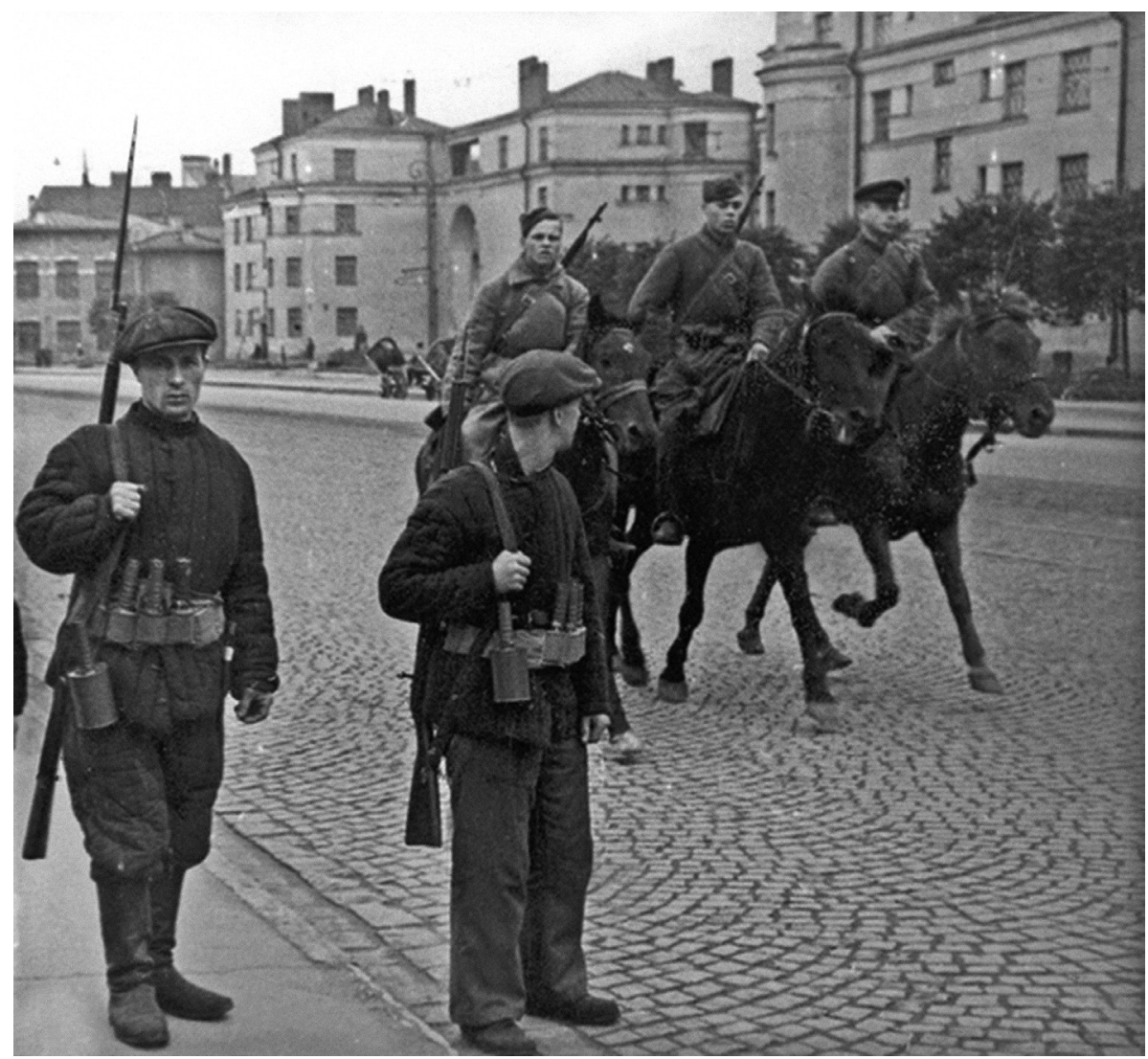

Ил. 4. Патруль рабочих Кировского завода и красноармейский разъезд на проспекте Стачек. 1941 г. Август 1941 г. (Ленинград в борьбе месяц за месяцем. 1941-1944, Санкт-Петербург 1993)

красноармейцев. ОАнако во время артобстрела была повреждена электрическая подстанция, и контактная сеть была обесточена. Трамваи встали там, где их застало откмючение, и были оставлены. Из-за бы-

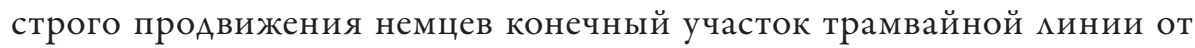
Привала до Стрельны с оставшимися на нем вагонами оказался на ок-

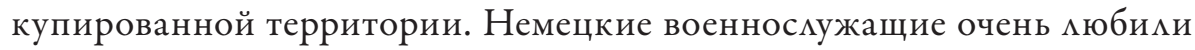
фотографироваться у этих вагонов, хвастаясь в своих письмах в «фатер-

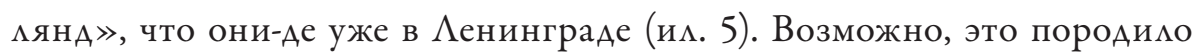
мегенду о мирном трамвае с горожанами, который якобы был варварски расстрелян наступающими фашистами. На Петергофском шоссе вагоны простояни до освобожАения этих мест в 1944 г. К моменту снятия 
блокады от «пленных» трамваев в кучшем случае оставацись только обгоревшие остовы ${ }^{8}$.

Красносельский район - еАинственный из аАминистративных районов современного Санкт-Петербурга, территория которого поцностью оказалась оккупированной противником. ЗАесь находимись Ава города - Красное Село и Урицк. Первый из них оказался в глубине занятой вра-

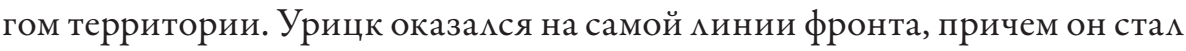
бцижайшим к $е$ енинграду пунктом под контролем немцев.

С приходом оккупантов в населенных пунктах Красносельского района начались тяжелые Ани. ГАавной проблемой стало отсутствие безопасности. Немцы требовали от местных жителей беспрекословного подчинения, за мацейшее неповиновение могци наказать расстрелом. В Красном Селе действовало отделение айнзацгруппы А бригаденфюрера СС Шталмекера. Ее задачей было выявление и миквидация «нежемательного элемента», в том числе партийных работников, советских активистов, евреев и цыган. 16 сентября 1941 г. в Красном Селе бы организован $\Lambda$ агерь Аля советских военнопменных. По воспоминаниям живших оккупацию, немцы организовали в Красном Селе несколько

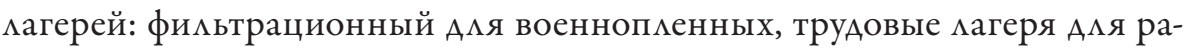
ботающих на жемезной дороге, Красногородской фабрике и на дорожных работах. Военнопленные использовацись как бесплатная рабочая сима, в первую очереАь ААя привеАения в порядок Аорожной сети и устранения поврежАений, причиненных в ходе боевых действий. Пценных кормили скудно, отчего они постоянно оставацись голодными. Среди них была высокая смертность'

Перед занятием немцами Красного Сема и примегающей местности

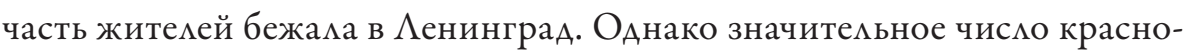

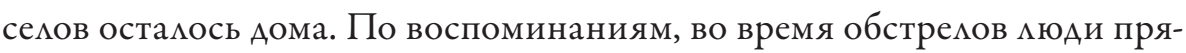
талась в щелях и подвалах, а когАа один из обстрелов окончился, вокруг уже быми немцы. Они организоваци комендатуру, которая провека учет населения. Это было нужно в первую очереАь Аһя организации принуАительных работ, к которым привлекались все трудоспособные. Гцавной

${ }^{8}$ М.Н. Величенко, Б.С. КАнторович, В.А. ПоПов, Аенинградский трамвай. 19411945, Санкт-Петербург 1995, s. 38-42.

9 В.Г. ПЕЖемСкий, Красное Село. Страницы истории, Санкт-Петербург 2016, s. 466. 


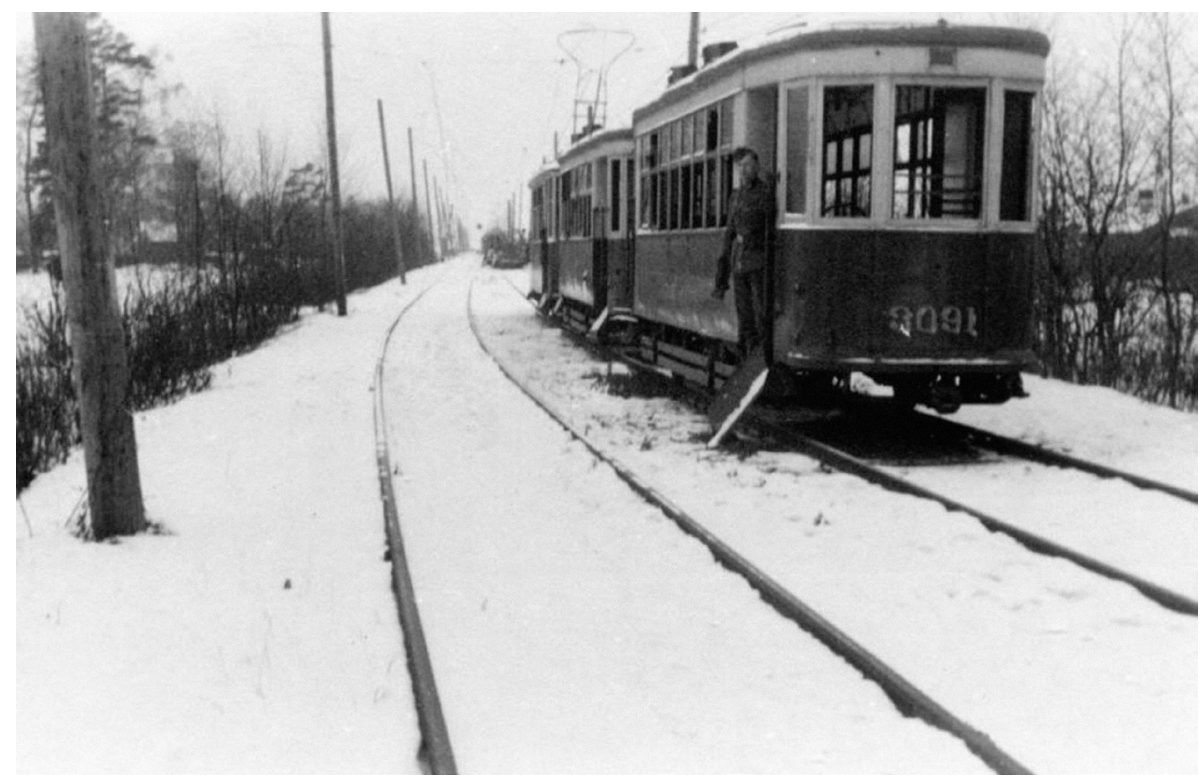

Ил. 5. Немецкий солдат на подножке вагона ЛП-33 на Петергофском шоссе. 1941/1942 г. (Фот. неизвестен)

проблемой Аля жителей было отсутствие продовольствия. Немцы не собирались кормить местное население, наоборот, они использовали проАовольственные запасы в своих интересах. Осенью 1941 г., парал ельно с голодом, который начинался в блокированном Аенинграде, начался голод и в оккупированных пригородах. Жители деревень использовали спрятанные запасы, у горожан такие запасы были не всегда. Считается, что в Красносельском районе в его прежних границах, т.е. с Русско-Высоцким, Ропшей, Кипенью и т. А., за время оккупации 2355 человек умерло от голода, 2885 погибло от бомб и снарядов.

Особенно тяжелая участь постигла тех, кого немцы выселили из прифронтовых Горелова и Урицка. По воспоминаниям Н. И. Щекиной, беженцев поселили в Красном Селе в отАельном здании. Находившихся при смерти от голода выносили на чердак умирать. Зимой копать могилы

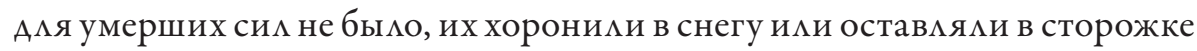
у входа на кладбище, в которой выломали пол. Весной немцы заставили перенести тела умерших в землю10.

${ }^{10}$ Ibidem, s. 470-481. 
К началу Вемикой Отечественной войны на территории Аенинградской

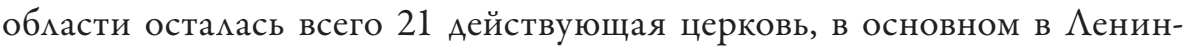
граде и пригородах. Аве из них находились в Красносельском районе: Преображенская церковь в Урицке и церковь Св. ААриана и Наталии в Старо-Панове. Обе они вскоре перестали действовать. Настоятель Преображенской церкви в Урицке протоиерей Иоанн Чудович 19 сентября 1941 г. бым выслан немцами в Тайцы, богослужения в храме прекратились, а сам он в Аальнейшем был разрушен. Храм в Старо-Панове оказался на $и$ ини фронта и симьно пострадац от военных действий, службы в нем также прекратимись. В местах, удаценных от минии фронта, немецкие оккупанты, наоборот, могми разрешить открыть храм, закрытый советскими вцастями. ОАнако попытка иеромонаха Тихона Зорина возродить церковь Св. Андрея Критского на станции Володарская закончилась неудачей. Он смог получить разрешение мишь на открытие привокзацьной часовни, в которой в январе 1942 г. устроиц церковь. ОАнако она Аействоваца меньше трех месяцев. 23 марта 1942 г. оккупанты в принудительном поряаке выселили всех жителей пристанционного поселка в Волосовский район, и храм вновь перестал действовать.

Несколько храмов сумел возродить престарелый священник отец Иоанн Пиркин, служивший в 1930-е гг. в Красном Селе. 30 ноября 1941 г. он открым Покровскую церковь в Мариенбурге (сейчас часть Гатчины), в феврале 1942 г. освятим Троицкую церковь в Красном Селе. Некоторое время в 1942 г. священник, очевиАно, обслуживац и Троицкий храм в поселке Самопомощь, а также возобновленную Никольскую церковь в поселке ЯмИжора. Отец Иоанн служим в Красном Селе почти два года, моцясь, по свидетемьству прихожан, «за страну родную, за наших бойцов Красной армии» и о Ааровании скорой победы наА гитлеровцами. В конце 1943 г. священник бым вывезен немцами в Аитву, где вскоре сконча ся ${ }^{11}$ (иц. 6).

Захватив Урицк, немцы оказацись в непосредственной близости от городской черты. Захватчики могли видеть жимые и производственные кварталы южных районов Аенинграда в бинокмь. Кировский район стал передним краем обороны советских войск. На случай умичных

${ }_{11}$ М.В. Шка Ровский, Церковь зовет кзащите Родины. Религиозная жизнь Аенинграда и Северо-Запада в годь Великой Отечественной войны, Санкт-Петербург 2005. 


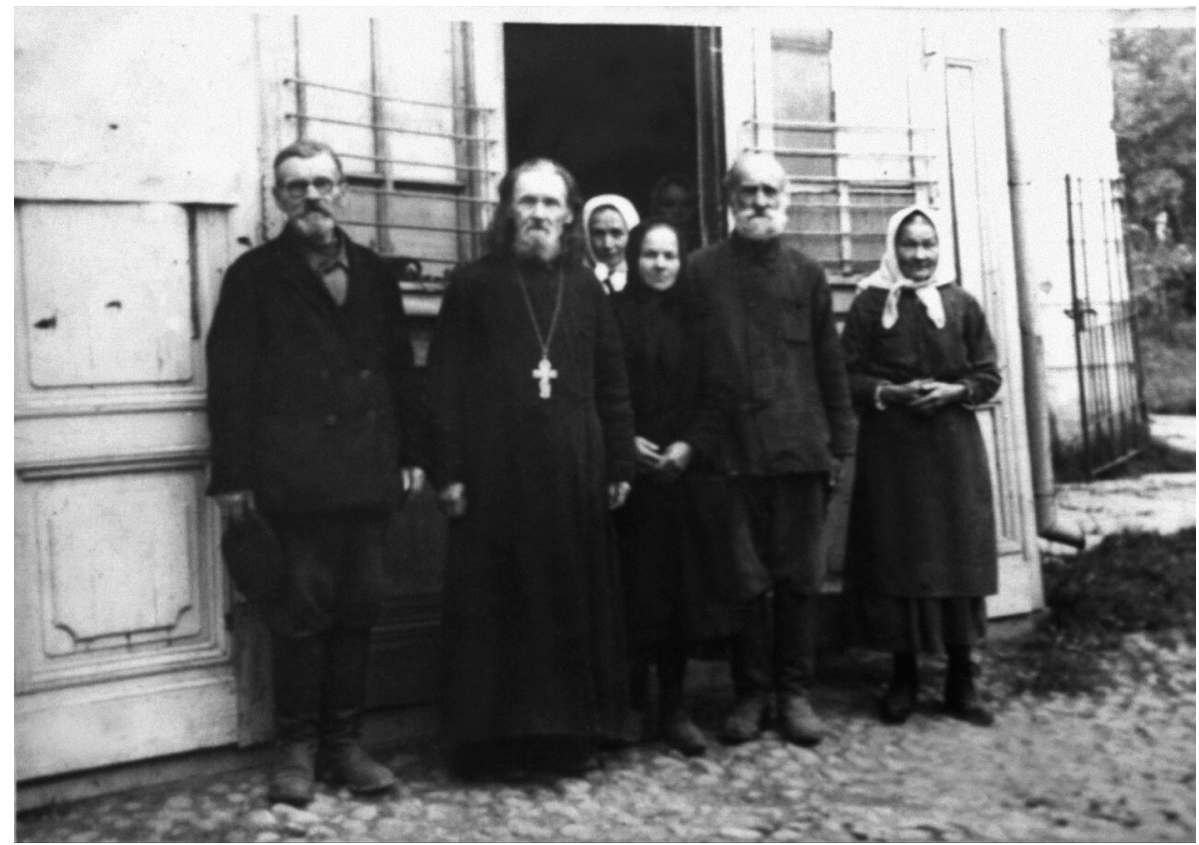

Ил. 6. У входа в церковь Св. Троицы. Красное Село. 1943 г. (Фот. неизвестен)

боев строились баррикаАы, перекрывающие основные проезды. В угловых домах оборудовацись пулеметные гнезда и амбразуры Аля орудий. Сооружались доты - долговременные огневые точки из железобетона. Большинство привлеченных к этим работам состав яли женщины. К 23 сентября 1941 г. по 1-му сектору обороны Аенинграда (Кировский и Аенинский районы) было вырыто ими создано тысячи погонных метров противотанковых рвов, эскарпов, окопов и «противотанковых $о$ вушек», организованы командные пункты, поставцены железобетонные надолбы, устроены 16930 проволочных заграждений в оАин, три и пять рядов кольев. Заложены фугасные снаряды и более 20 тысяч мин. СозАаны Аесятки Азотов Аля 76-мм и 45-мм оруАий и пулеметов.

ОАной из важнейших проблем Аля жителей Кировского района, как и Аля всех менинградцев, был холоА. Из-за остановки теплоэлектростанций и отсутствия подвоза топ ива квартиры, особенно в центре города, начами замерзать. Горожане начами стихийно разбирать многочисленные деревянные постройки - сараи, заборы, киоски. 24 декабря 
1941 г. Аенгорисполком разрешил разбирать на дрова деревянные дома и Аругие строения. $е$ енинградцы обогревали свои промерзшие квар-

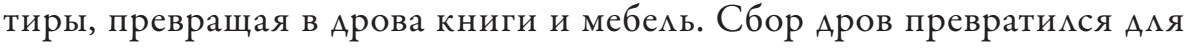
замерзающих кенинградцев в оАно из главных повсеАневных занятий. Горожане ежеАневно выходили на улицы города с топориками и ножами, чтобы набрать доски и щепу Аля домашних печек. Разбор домов происходиц бессистемно, нереАко этой участи подвергались зАания, поврежАенные артобстрелами ики авиабомбардировками. В сентябре 1942 г. ситуация изменилась. 1 сентября 1942 г. в Аенинграде начался месячник по разборке деревянных домов на дрова, чтобы в течение месяца заготовить Арова в плановом порядке. Наметили 6000 зАаний, которые организованно, с привлечением тяжелой техники подверглись разборке. В месячнике в порядке трудовой повинности участвоваци все мужчины от 16 до 55 мет и женщины от 16 до 45. Каждый участник Аолжен был заготовить не менее 4 кубометров дров: Ава Аля себя, Ава - в общий топливный фонА. Всего по городу было снесено более 7 тыс. Аомов, что Аало 1 млн кубометров Аров. ОАнако, несмотря на механизированную помощь, горожане не смогли за сентябрь выполнить положенную норму заготовки дров, и 1 октября месячник был продлен еще на 20 Аней. БАагодаря преАпринятым мерам положение с топливом в $\Lambda$ енинграде зимой 1942/43 г. было намного кучше, чем в первую блокадную зиму ${ }^{12}$ (им. 7).

Настоящим бедствием в годы Великой Отечественной войны стала детская беспризорность. В блокадном Аенинграде взрослые умирали от голода, во время обстрелов, а те, кто были живы, часто не имели сил дойти Аомой с работы. У подавляющего большинства детей отцы быми на фронте, многие убиты. Аети оставаАись одни. Меры по борьбе с беспризорностью принимались весь 1942 гоА. К марту 1942 г. в Аенинграде работало почти сто Аетских домов, но этого было недостаточно. Февральским приказом 1943 года милиции было поручено обеспечить выявление и изъятие беспризорных и безнадзорных Аетей, организовать систематические обходы мест их возможного пребывания; возобновить при отдемениях мимиции работу детских комнат, обеспечив в них необходимый санитарный минимум и запретить содержание задержанных детей вместе со взрослыми;

12 Аенинград. Юго-западньй рубеж..., s. 127. 


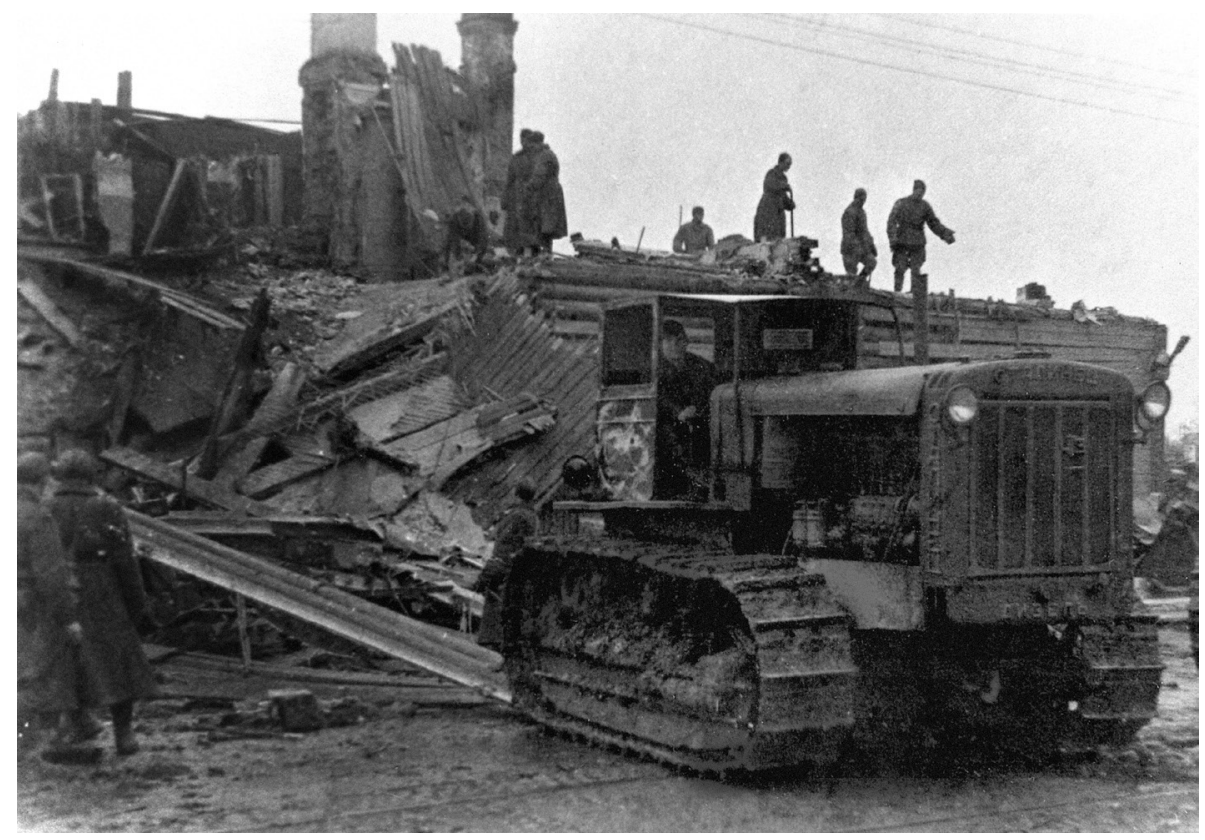

Ил. 7. Слом деревянного дома на дрова на проспекте Стачек в Кировском районе.

Сентябрь 1942 г. (Фот. В. Г. Федосеев, ЦГАКФФД СПб)

обеспечить тщательную фимьтрацию задержанных детей, и тех из них, которые не имеют родителей, направцять в бцижайшие детские приемники-распредемитеми. Чтобы спасти их от гибели, а также чтобы предотвратить Аетскую и подростковую преступность, малышей переАаваци в Аетские Аома, Аля ребят постарше открывали ремесленные учимища и фабрично-заводские школы. Подростки с 14 лет могли работать. Аетей, чьи судьбы были искалечены войной, старацись, насколько это было возможно, вернуть к нормацьной жизни в обществе ${ }^{13}$.

Особенностью современных Кировского и Красносельского районов яв яется оби ие сохранившихся на их территории железобетонных укреплений. 20 мая 1943 г. началось строительство оборонитемьного рубежа «Ижора», начальный участок которого прошел через Кировский район. Несмотря на прорыв блокады и улучшение ситуации со снабжением, угроза прорыва противника в Аенинград не исчезца. Поэтому в 1943 г.

13 Ibidem, s. 134-135. 


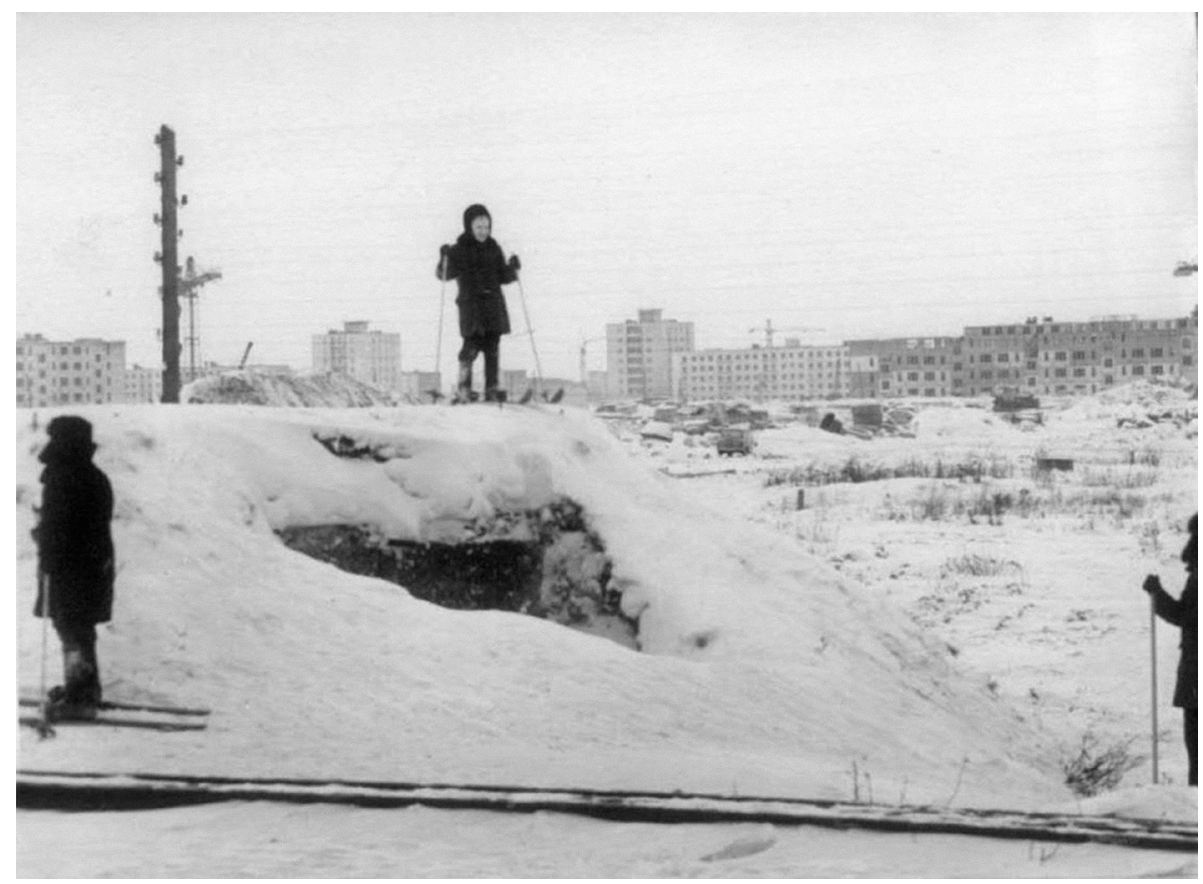

Ил. 8. Дот, стоявший на бывшей линии обороны Ленинграда. 15 января 1963 г.

(Фот. М.Л. Блохин, ЦГАКФФД СПб)

была проведена огромная работа по совершенствованию обороны, в ходе которой был сооружен пояс капитальных оборонительных сооружений из бетона на тыловом рубеже 42-й и 55-й армий, получивший условное название «Ижора». Рубеж начинался в Угольной гавани, его головной участок проходия по земле Кировского района. Жемезобетонные укрепмения, которые по качеству многократно превосходили кустарно возведенные укрепления 1941-1942 гг., сооружали стройармейцы, в первую очередь женщины. На строительстве оборонительной кинии трудились около 2000 человек, причем работать приходилось под огнем противника, передний край которого находияся на расстоянии от 800 м до 5 км. При возведении рубежа «Ижора» было убито и ранено более 100 человек. Всего к 1 октября было построено 119 фортификационных сооружений, в том числе 92 железобетонных артилмерийских и пулеметных Аота, оснащенных современным оружием и всеми среАствами жизнеобеспечения. Капитальные железобетонные сооружения рубежа «Ижора» 


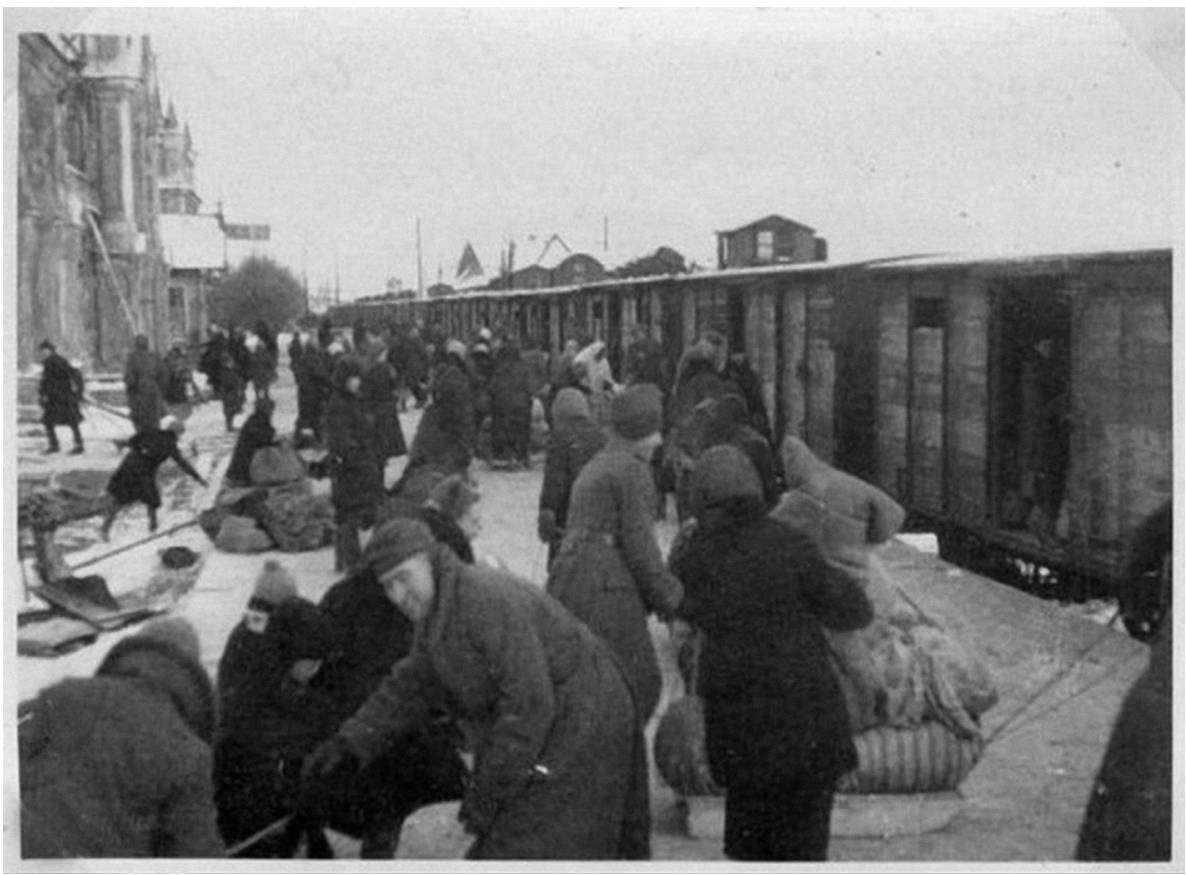

Ил. 9. Посадка в поезд на Красносельском вокзале. 1943 г. (Фот. неизвестен)

были возведены настолько качественно, что в мирное время их не всегда УАавалось демонтировать. Иногда приходимось отрывать рядом с Аотом котлован и хоронить в нем все сооружение целиком. Отчасти в связи с этим обстоятельством значительное количество дотов «Ижоры» сохранимось до нашего времени (им. 8). В 2015 г. все сохранившиеся сооружения оборонительного рубежа «Ижора» (36 дотов) были признаны комплексным объектом культурного наслеАия регионального значения. Аот № 112 у дома 79 по проспекту Стачек, преАстав явший собой пулеметную огневую точку с амбразурой поА казематную шаровую 7,62-мм пулеметную установку, в настоящее время музеефицирован ${ }^{14}$.

В отличие от советских дотов, сохранившиеся немецкие укрепления остаются заброшенными. Из них демонтировано оборудование, но разрушать их, особенно если их существование не мешало строительству, не

${ }_{14}$ Н. Филиппов, В рядах военных строителей (женские инженерные войска блокадного Аенинграда), „БАокнот агитатора” 1977, № 1, s. 35-40. 
стали. На территории Красносемьского района сохранимось нескомько Ringstande, более известных как «тобруки» - укреплений из бетона, рассчитанных на размещение пулемета или 50-мм миномета. Гарнизон симой до трех человек размещался на позиции комьцевого типа с входом через боковую Аверь ${ }^{15}$.

После установления стабимьного фронта осенью 1941 г. немцы высемими жителей прифронтовой полосы, в частности, Урицка, Старо-Панова, Володарского. Кто-то из них оказался в Красном Селе, кто-то бы отправлен в Волосовский район. Аетом 1943 г. немцы, опасаясь советского наступцения, стаци готовить эвакуацию жителей Красного Сема. Жителям объявими, что якобы готовится штурм Аенинграда, красноселы окажутся в полосе наступления и Аля их же безопасности им надо переселиться. Русские полицаи разносици по домам повестки, в которых указывалось, когда и куда следовало явиться. Предписывалось упаковать годные вещи и поставить у Аверей, разрешалось брать коров. На сборы отводицось 24 часа, невыполнение приказа жестоко каралось. 30 сентября 1943 г. немецкие оккупанты завершили принудительное выселение жителей из Красного Села и Аудергофа. Основная масса быма направмена в Эстонию, инвацидов вывезци в Опочку за Псковом. Оккупанты организоваци отправку населения по-немецки педантично. Прибывшие на сборный пункт с вещами грузи ись в товарные вагоны и в тот же день отправ ялись в Прибалтику (им. 9). Часть угнанных жителей была размещена в качестве работников у местных крестьян, Аругих отправими в Германию, где они батрачими в немецких хозяйствах. На 1 января 1943 г. в Красном Селе насчитывалось 3438 жителей, детей - 816, беженцев - 261 человек. В январе 1944 г., когАа 63-я и 64-я гвардейские стрелковые Аивизии освобождали Аудергоф и Красное Село, в этих населенных пунктах гражданского населения не было. Вернуться на родину красноселы смогли только после окончания войны, пройАя мытарства фильтрационных $а$ агерей.

В условиях стабильности фронта с осени 1941 г. до января 1944 г. противоборствовавшие стороны активно испоцьзоваци минные поля. При отступцении немцы допомнительно установици значительное количество

15 А.С. Тулупов, Оборонительные сооружения немещких войск под Аенинградом, СанктПетербург 2003. 


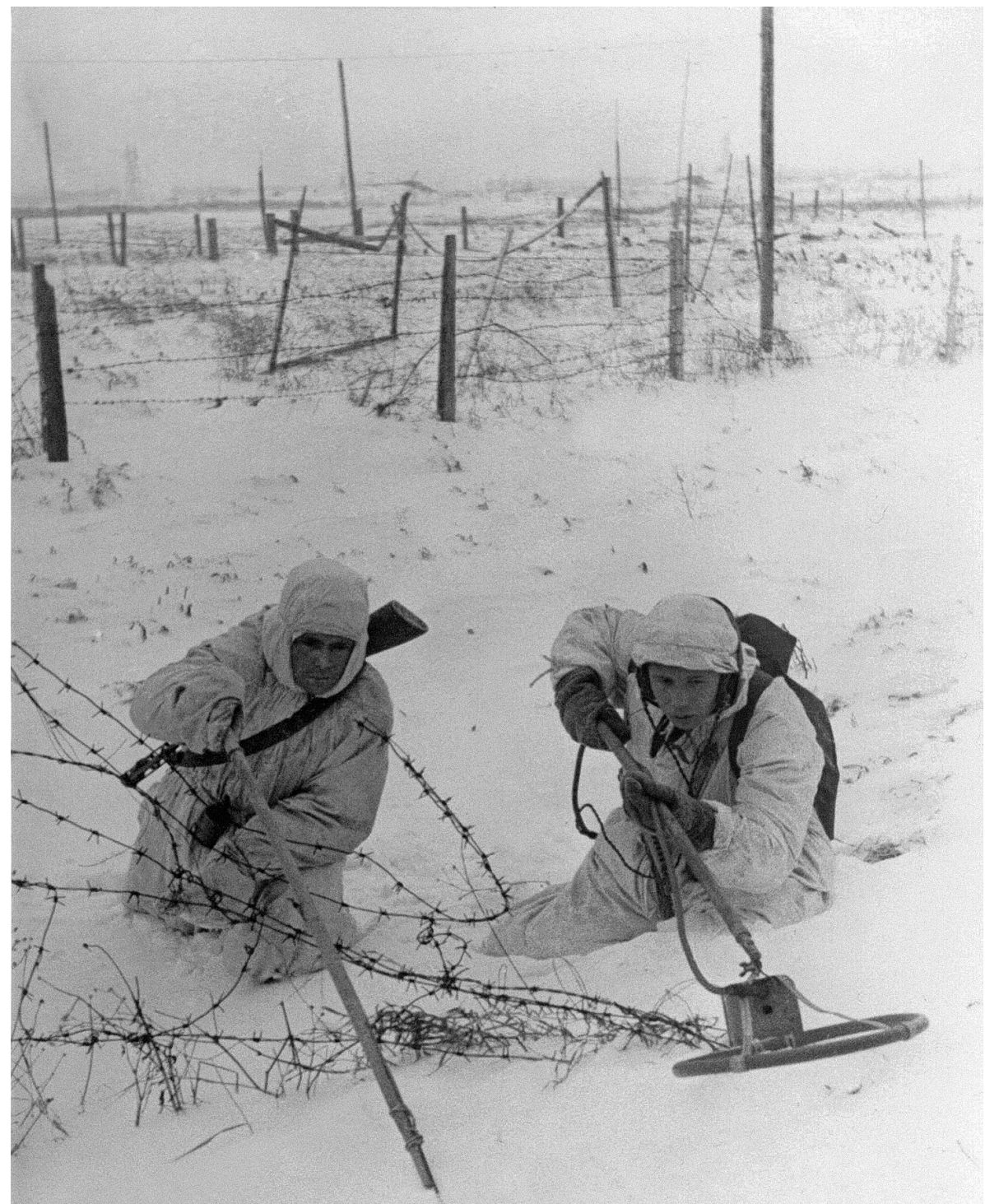

Ил. 10. Разведчики-минеры гвардии сержант Ф. Н. Пулатов и гвардии рядовой М. А. Богданов (слева), обезвредившие более 4000 вражеских мин разных конструкций, за разминированием. Ленинградский фронт. Январь 1944 г. (Фот. неизвестен, ЦГАКФФД СПб) 
мин на дорогах Аля замеАления наступцения советских войск. В частности, шоссе Красное Семо - Урицк было заминировано заранее, а Аля проезаа были оставлены коридоры, которые закрывались «минными шлагбаумами» из 3-5 мин, укрепленных на досках. Находившийся на переднем краю вражеской обороны Урицк, превращенный в груду развацин, преАстав я собой сп ошную зону минных полей, причем в основном устанавцивацись противотанковые мины. Советские саперы отмечами густоту минирования - в отдемьных местах мины находицись на расстоянии 1 м оАна от Аругой. В ходе наступления советские саперы разминироваци в первую очередь Аороги и места расквартирования войск, большая

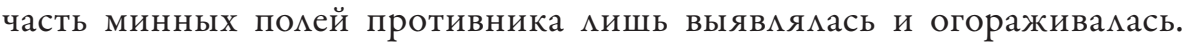

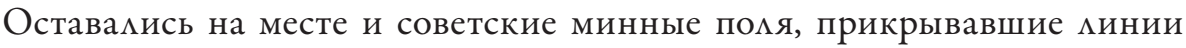
обороны вокруг Аенинграда, которые в 3,5 раза превосходими немецкие по количеству мин. 15 октября 1943 г. в преААверии освобожАения Аенинградской обцасти от оккупантов начацось обучение гражАанских специалистов по разминированию. В апреле начацось сплошное разминирование на территории площаАью 1073 кв. км. В помощь инженерным частям было выделено 1500 человек из частей МПВО Аенинграда, 50 бойцов всевобуча и 500 человек от управления НКВА АенинграАской области. Аля руководства работами и проведения контрольной проверки фронт выдемим инженерный батацьон и батацьон собак-миноискатемей ${ }^{16}$ (им. 10).

В результате военных действий инфраструктура значительной части Кировского и Красносельского районов быма уничтожена. После окончания блокады в $\Lambda$ енинграде началось восстановцение разрушенного. На юго-западе восстанавцивать было в значитемьной мере нечего. ЗАесь инфраструктура формировалась фактически заново, опираясь на отдельные уцелевшие объекты. В фронтовых Урицке, Аачном, УАьянке изменилась Ааже трассировкаулиц, обычно наиболее консервативный элемент инфраструктуры. Неудивительно, что именно здесь, на юго-западе $\Lambda$ енинграда,

16 Разминирование местности на Северо-Западе Российской Федерации (1944-2013 г2.) Аокументы и материаль, [w:] Труды научно-исследовательского отдела Института военной истории, реА. Э.А. Коршунов, т. 8, Санкт-Петербург 2014, s. 23; С.Б. БорзЕнко, А.О. КожЕмякин, М.А. АЕвчЕнко, Аенинград в ожидании победь- 1944-1945: к 70-летию Победь в Великой Отечественной войне, Санкт-Петербург 2015, s. 23. 


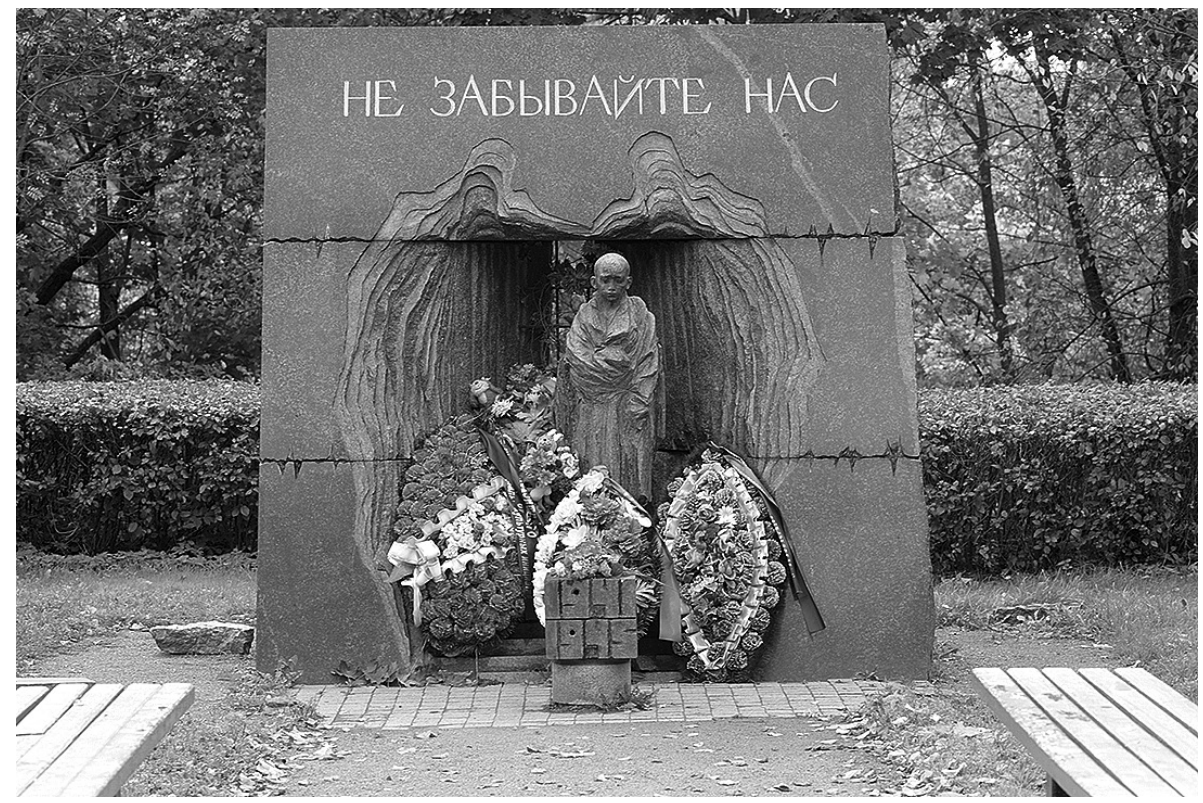

Ил. 11. Памятник детям-узникам нацистских концлагерей в Красном Селе (Фот. И. Садова)

в начале 1960-х гг. начацся процесс массового жицищного строитецьства, полностью изменивший обцик этих мест ${ }^{17}$.

Сохранить память о блокадных Анях - Анях отчаяния и мужества - было святой обязанностью тех, кто восстанавцивац город после войны. И квинтэссенцией памяти о блокаде, о городе-фронте стац юго-запаА-

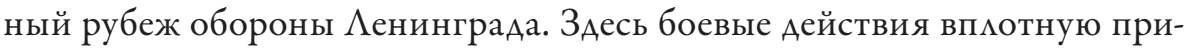
близимись к границе города; зАесь всю войну работал Кировский завоА, поставцяя оружие и технику на фронт; здесь бым возведен Ижорский оборонительный рубеж, призванный преграАить врагу Аорогу в случае штурма города; здесь $\Lambda$ енинграА встречал воинов-победителей. Поэтому в современных Кировском и Красносельском районах по-особому хранят память о войне, блокаде и Победе. Тематика названий умиц и других важных объектов в этих районах призвана напоминать о героях и героических Аеяниях советских мюдей. ЗАесь начинается «Земеный пояс

17 А.З. ВАкСер, Аенинград послевоенный. 1945-1982 годъц, Санкт-Петербург 2005, s. $174-$ 178; Незабытый Аенинград, Санкт-Петербург 2016, s. 176. 
Славы» - повторяющая минию фронта цепочка монументов и мемориалов, посвященных проходившим здесь в 1941-1944 гг. боям. Алмея Славы, обелиски на захоронениях павших воинов, уникальные танки на постаментах, сохраненные и музеефицированные доты, посвященные отдельным героям школьные музеи - все здесь призвано хранить память о трагических и героических одновременно Анях великой борьбы, завершившихся незабываемой Великой Победой (ик. 11)

\section{Bibliografia}

\section{Źródła drukowane}

Разминирование местности на Северо-Западе Российской Федераџии (1944-2013 г2.). Аокументы и материаль, [w:] Труды научно-исследовательского отдела Института военной истории, т. 8, реА. Э.А. Коршунов, Санкт-Петербург 2014 (Razminirovaniye mestnosti na Severo-Zapade Rossiyskoy Federatsii (1944-2013 gg.). Dokumenty i materialy, [v:] Trudy nauchno-issledovatel'skogo otdela Instituta voyennoy istorii, t. 8, red. E.L. Korshunov, Sankt-Peterburg 2014).

\section{Opracowania}

Блокада рассекреченнал, сост. В.И. Аемидов, Санкт-Петербург 1995 (Blokada rassekrechennaya, sost. V.I. Demidov, Sankt-Peterburg 1995).

Борзенко С.Б., Кожемякин А.О., Аевченко М.А., Аенинград в ожидании победъ - 19441945: к 70-летию Победь в Великой Отечественной войне, Санкт-Петербург 2015 (S.B. Borzenko, Kozhemyakin A.O., Levchenko M.A., Leningrad v ozhidanii pobedy - 1944-1945: k 70-letiyu Pobedy v Velikoy Otechestvennoy voyne, Sankt-Peterburg 2015).

Ваксер А.3., Аенинград послевоенный. 1945-1982 годы, Санкт-Петербург 2005 (Vakser A.Z., Leningrad poslevoyennyy. 1945-1982 gody, Sankt-Peterburg 2005).

Величенко М.Н., Канторович Б.С., Попов В.А., Аенинградский трамвай. 19411945, Санкт-Петербург 1995 (Velichenko M.N., Kantorovich B.S., Popov V.A., Leningradskiy tramvay. 1941-1945, Sankt-Peterburg 1995).

Кантор Ю.З., Эвакуащия из Аенинграда и Аенинградской области, [w:] Побратимвl. Регионам, принявшим эвакуированных ленинградиев, посвящается, реА. Ю.З.

18 Аенинград. Юго-западныцйрубеж..., s. 195-211. 
Кантор, Санкт-Петербу́рг 2019, s. 9-54 (Kantor Yu.Z., Evakuatsiya iz Leningrada $i$ Leningradskoy oblasti, [v:] Pobratimy. Regionam, prinyavshim evakuirovannykh leningradtsev, posvyashchayet.sya, red. Yu.Z. Kantor, Sankt-Peterburg 2019, s. 9-54).

Аенинград. Юго-западньй рубеж, Санкт-Петербург 2020 (Leningrad. Yugo-zapadnyy rubezh, Sankt-Peterburg 2020).

Мосунов В.А., Борьба за Пулковский рубеж в сентябре 1941 года, [w:] Война и оружие. Новые исследования и материаль. Трудь Третьей Международной научнопрактической конференции 16-18 мая 2012 года, реА. С.В. Ефимов, СанктПетербург 2012, s. 384-399 (Mosunov V.A., Bor'ba za Pulkovskiy rubezh v sentyabre 1941 goda, [v:] Voyna i oruzhiye. Novyye issledovan Trudy Tret'yey Mezhdunarodnoy nauchno-prakticheskoy konferentsii 16-18 maya 2012 goda, red. S.V. Yefimov, SanktPeterburg 2012, s. 384-399).

Незабътый Аенинград, Санкт-Петербург 2016 (Nezabytyy Leningrad, Sankt-Peterburg 2016).

Пежемский В.Г., Красное Село. Странищы истории, Санкт-Петербург 2016 (Pezhemskiy V.G., Krasnoye Selo. Stranitsy istorii, Sankt-Peterburg 2016).

Пянкевич В.А., Чистиков А.Н., Пешком по озеру: эвакуачия населения из Аенинграда в конце ноября-начале декабря 1941 г., „Новейшая история России” 2019, т. 9, № 1, s. 56-69 (Pyankevich V.L., Chistikov A.N., Peshkom po ozeru: evakuatsiya naseleniya iz Leningrada $v$ kontse noyabrya - nachale dekabrya 1941 g., „Noveyshaya istoriya Rossii" 2019, t. 9, nr 1, s. 56-69).

Саврасов И.Ю., Кировский завод в годь Великой Отечественной войнь,, [w:] Аенинград. Война. Блокада. Город-фронт, сост. П.В. Игнатьев, Э.А. Коршунов, А.И. Рупасов, Санкт-Петербург 2019 (Savrasov I.Yu., Kirovskiy zavod vody Velikoy Otechestvennoy voyny, [v:] Leningrad. Voyna. Blokada. Gorod-front, sost. P.V. Ignat'yev, E.L. Korshunov, A.I. Rupasov, Sankt-Peterbyrg 2019).

Сувениров О.Ф., Помощь Аенинграда фронту людьми в первую блокадную зиму. Вторая мировая война, Кн. 2: Военное искусство, Москва 1966 (Suvenirov O.F., Pomoshch' Leningrada frontu lyud'mi v pervuyu blokadnuyu zimu. Vtoraya mirovaya voyna, Kn. 2: Voyennoye iskusstvo, Moskva 1966).

Тулупов А.С., Оборонительные сооружения немещких войск под Аенинградом, СанктПетербург 2003 (Tulupov D.S., Oboronitel'nyye sooruzheniya nemetskikh voysk pod Leningradom, Sankt-Peterbyrg 2003).

Фимиппов Н., В рядах военных строителей (женские инженернье войска блокадного Аенинграда), „БАокнот агитатора” 1977, № 1, s. 35-40 (Filippov N., V ryadakh voyennykh stroiteley (zhenskiye inzhenernyye voyska blokadnogo Leningrada), „Bloknot agitatora" 1977 , nr 1, s. 35-40).

Шкаровский М.В., Церковь зовет к защите Родины. Религиозная жизнь Аенинграда и Северо-Запада в годы Великой Отечественной войнь, Санкт-Петербург 2005 (Shkarovskiy M.V., Tserkov' zovet k zashchite Rodiny. Religioznaya zhizn'Leningrada i Severo-Zapada v gody Velikoy Otechestvennoy voyny, Sankt-Peterbyrg 2005). 


\title{
Denis Alekseev, Aleksey Kozhemyakin, Yuliya Minutina-Lobanova \\ SPECIFIC FEATURES OF THE SOUTH-WESTERN SUBURBS OF LENINGRAD DURING THE SIEGE, 1941-1944
}

\begin{abstract}
Summary. During the siege of Leningrad its South-Western suburbs, which now consist of Kirovskiy and Krasnoselskiy districts, had the most unusual fates. Krasnoselskiy district was the only part of modern St. Petersburg which was seized by Germans. Its inhabitants suffered from forced displacements and terror politics of the occupants. Kirovskiy, on the other hand, formed first line of the Soviet defense, besides its factories tried to keep on working. But, nevertheless, the both districts shared common features: hunger, artillery bombardment (from different sides), total destruction of infrastructure, depopulation. After the war the both districts turned into a large construction site, where first projects of Soviet-style large-panel construction were implemented. Now the districts possess a great number of places of memory connected to the World War II - old pillboxes, soldier cemeteries, monuments, memorial plates. Most of streets here are named to remind us events of the siege of Leningrad and the World War II.
\end{abstract}

Keywords: World War II, Soviet-German front, siege of Leningrad, South-Western suburbs of Leningrad, city, German occupation 